\title{
The Growth of Amish and Plain Anabaptists in Kentucky
}

\author{
Joseph Donnermeyer ${ }^{1}$ \\ Professor Emeritus \\ School of Environment and Natural Resource \\ The Ohio State University \\ Cory Anderson \\ Adjunct Professor \\ Rural Sociology \\ Ohio State Agricultural Technical Institute
}

\begin{abstract}
This article examines the growth of Amish and plain Anabaptist communities and population in Kentucky, one of the few southern states with a sizeable plain Anabaptist presence across much of its rural areas. Within the Amish religious tradition, this study focuses on both the broadly defined Old Order Amish, namely, those who prohibit ownership of motor vehicles for transportation, and the Amish-Mennonites, those who allow ownership. We provide an overview of their community formation and present a county-based estimate of their population. There are now 53 Amish communities in Kentucky, and a population of nearly 10,000. Over half (27) of these communities were founded since the turn of the century. Non-Amish, plain Anabaptists constitute 33 congregations.
\end{abstract}

\section{Keywords}

Old Order Amish; New Order Amish; Swartzentruber Amish; Amish-Mennonites; Ambassadors Amish-Mennonites; Old Order Mennonites; Conservative Mennonites; Intentional churches; Church districts; Settlements; Community migration

\section{Note}

This profile of the Amish is the second in an anticipated series of articles whose intent is to provide regionally based spatial-demographic descriptions of Amish communities. The first described buggy-driving Amish churches in Iowa (Cooksey and Donnermeyer 2013). 


\section{Introduction}

From a sociological point of view, the Amish can be described as a subculture, religious sect, and ethnic group (Anderson 2013a; Hostetler 1993, 5-18; McQuire 2002, 163). These concepts point toward a group of people who are neither fully assimilated into, nor compatible with, mainstream American culture. For instance, men from the conservative Swartzentruber sect of Amish in Graves County of far western Kentucky went to jail rather than abide by a state law requiring reflective orange triangles on the backs of their buggies. The reasons for their resistance eventually prompted the state legislature to rescind the law, allowing instead lightreflective tape outlining the backs of their buggies, a technology compatible with their religious beliefs (Associated Press 2012).

Kentucky is replete with other sects, especially fundamentalist and evangelical Christian groups, some of whom believe that salvation can and should be displayed by holding poisonous snakes during their church service, speaking in unknown languages, and shaking and writhing on the floor (Woodberry and Smith 1998; Emerson and Hartman 2006). These sects stand in sharp counterpoint to the Amish. For fundamentalist sects, salvation is displayed through highly individualized and emotional displays of faith (Conkin 1997, 304-05), while for the Amish, salvation is through participation in and conformity to a community of like-minded believers (Hurst and McConnell 2010, 23-25).

Citing definitions of modernity by Berger, and Weber's concept of Wertrational (value rational), Enninger (1988), Kraybill (1989, 251-52, 283; 1994, 25-33), and Olshan (1981) argue that the Amish are modern traditionalists in that they self-consciously and selectively restrain community lifestyle options to achieve a desired value-based end. Sociological concepts of modernity emphasize both the transformative effect of technology on social structure and on related cultural changes that underpin the beliefs, values, and ideologies of large scale, complex societies when compared to pre-industrial arrangements (Berger, Berger, and Kellner 1973; Giddens and Pierson 1998). However, societies like Canada and the United States-already transformed by the forces of modernity-yet have room for numerous religious subcultures or sects, such as the Amish and other plain Anabaptist groups, who seek to maintain separation from the mainstream, physically, socially, and culturally.

The plain Anabaptists have arrived in Kentucky through migration. But how have they migrated? And why? Anderson (2012b) extends the subcultural dimension of distinctive religious groups to include community-level motivations for why people migrate, emphasizing the role of religious values. By extending the analysis of migration beyond individual-level factors, that is, net benefits versus costs, Anderson's theoretical framework emphasizes the important role of networks and affiliation-level capital in relocation. Applied to religious subcultures, such as the Amish, the focus shifts from the decision-making of individual/single households to the communal or collectivistic dimensions of establishing new communities, especially among more intentional groups who seek to maintain their distinctiveness. Hence, the establishment of new 
communities is for the Amish a conscious attempt to replicate and sustain patterns of social organization and religious beliefs that symbolize their separation from the mainstream (Donnermeyer and Cooksey 2010).

The story of the Amish expansion into Kentucky over the past 50 years illustrates a collectivistic side to migration. The primary purpose of this article is to describe the growth of various Amish groups in the rural places of Kentucky, and then, secondly, explore the growth of other plain Anabaptists. All of the former identify themselves as coming out of the original 169394 division between the Swiss Brethren and groups identified by the spokesman Jacob Amman (Beachy 2011). We address two major paths within this religious tradition, namely, those whose church discipline focuses on both media / digital and convenience technologies (notably the proscription on automobile ownership) and those whose church disciplines only address media/digital technologies (consequently permitting automobile ownership). Within both groups is a great deal of diversity and difference; however, we will generally refer to the automobile proscribing groups as "Old Orders" and the automobile permitting groups as "AmishMennonite," as no other symbolic boundary cleanly delineates these two waves given the tremendous diversity now encompassing both historic paths. We use "Amish" as the word to describe both, and on occasion, we mention more specific and narrowly defined church groups by the specific name of their fellowship.

The history of the Amish in Kentucky harkens back to the establishment of a settlement in 1958 near the small town of Guthrie in Todd County. Their time in Kentucky is short when compared to the Amish presence in other parts of North America, which started with the first Amish arrivals to Pennsylvania from Europe in the early 1700s. Yet, Kentucky is significant because it represents one of the few southern states today where there is a sizeable Amish population and a large number of communities from both the Old Orders and the AmishMennonites (Donnermeyer and Cooksey 2010; Anderson 2012a). We conclude by considering their continued growth and development in Kentucky and the South in general.

\section{Methodological Notes}

Information for our accounting of the Old Order and Amish-Mennonite communities in the Bluegrass state is built on earlier work estimating their population throughout the United States for the Religious Congregational Membership Survey (Donnermeyer, Anderson, and Cooksey 2012). RCMS provides county-based estimates of denominational membership in the United States every ten years (Grammich, et al. 2012). This information is supplemented by news accounts from scribes / reporters that are published in three primary periodicals: The Budget, Die Botschaft, and The Diary. In all three, reporters often mention news related to the new community formation. ${ }^{3}$ Onsite visits, informants, directories, and literature reviews were also used to gather information for both the Amish groups and other plain Anabaptists. Pinpoints are based on GPS coordinates of settlement centers (for Old Order Amish) and meetinghouses (for Amish-Mennonites and other plain Anabaptists) generated from aerial maps. 
Recently, we presented a theoretical framework by which to understand plain Anabaptists' socio-spatial realities (Anderson and Donnermeyer 2013); we employ this framework to interpret the Kentucky Amish experience. An Amish community or settlement represents one or more local churches, which themselves consist of a cluster of physically proximate families who have the ability to engage in collective activities. As in historic Amish settlements, Kentucky settlements can in time grow to encompass several local affiliations. A local affiliation is a group of churches that share intimate religious associations with each other represented through symbolic conformity in areas like dress and transportation mode (i.e. the same Ordnung), while a secondary local network recognizes those neighbors with different Ordnungs that nevertheless share the same higher order faith statements (e.g. the Dortrecht Confession of Faith) (Raith 2003). Throughout Kentucky, two or more orders of Old Order Amish or Amish-Mennonites (or other plain Anabaptists) may occupy the same area, creating a multi-affiliation settlement.

Amish settlements indeed function like communities, even though they do not possess legally established jurisdictions through which services are provided and taxes are levied. We use the words community and settlement synonymously. Many Amish refer to their localities as settlements, which, coincidentally, conforms to both older (Warren 1978) and newer (Liepins 2000) sociological definitions of community. Even those Amish places with small church membership behave as geographically based social systems. For example, Liepins (2000, 29-31) provides a definition of community, which she specifies as a product derived from the interaction of people, practices, and meanings which are embedded in spaces and structures. From these emerge "temporally and locationally specific terrains of power and discourse" (30).

These conceptualizations of community are essentially the same employed by Luthy (2009), who periodically has published a list of Old Order Amish communities (see also Donnermeyer and Luthy 2013). His specifications are minimalist, being based on only two requirements: the presence of at least three families who live near each other and their ability to hold a church service, perhaps the most important collective activity for the Amish, even if the service cannot be held without other Amish visiting from nearby communities. Hence, we follow his operationalization of “settlement” because of its consistency with both Warren's (1978) and Liepens' (2000) definitions. An added advantage of a minimalist definition is that it increases consistency and reliability for what counts as a community. For example, would the number be set at a higher level—say ten households—-then it creates the possibility that a cluster of anywhere from three to nine Amish households would be able to hold a church service but would not be counted because the minimal number was arbitrarily set at ten.

Few communities are as small as three households (and none at present). In most cases, if a new community does not soon grow large enough to acquire its own ministers, it will likely become extinct in a short time, with the households dispersing to more established settlements elsewhere. Hence, across the Amish spectrum, many small communities consist of only one church group and a handful of families, contrasting against a few large settlements with hundreds 
of church groups and thousands of families (Donnermeyer and Cooksey 2010).

\section{The Development of Old Order Amish Groups and the Amish-Mennonites}

The less progressive Amish came to be known as the Old Order Amish after a division between these more tradition-minded Amish churches and more progressive church groups during and following the Civil War (Beachy 2011; Nolt 2003). Those Amish affiliations specifically referred to as "Old Order Amish" remain the largest (about 85\%) of several major buggy-driving fellowships that are also in their automobile rejecting totality referred to in this article as the Old Orders. During the twentieth century, several other affiliations splintered off from the Old Orders. Each consists of churches that are in general agreement about their church discipline and would fellowship with each other, such as by allowing visiting ministers to preach.

Unlike the division during the Civil War years, many of the twentieth century fissions were internal and did not seriously decrease the number of people who identified themselves as of the Amish religious tradition (Anderson 2012a; Nolt 2003, 265-66 and 315-16; Hurst and McConnell 2010, 37-52). Mostly, the divisions were instigated by differences over specific practices in the church discipline (see Cong 1992 and Zimmerman Umble 1994 for cases). Among the Old Orders today, both progressive fellowships, such as the New Order Amish, and conservative fellowships, such as the Troyer, Dan, and Swartzentruber Amish, exist in addition to those falling under the standardized "Old Order" moniker (Hurst and McConnell 2010; Waldrep 2008). All have held the line against ownership of a motor vehicle, and in that sense, are considered as simply either more progressive or less progressive variants of the Old Orders. Specifically, several Amish communities in Kentucky are composed solely of a conservative variation on the Old Orders, the Swartzentruber Amish. It was men from the Swartzentruber community of Mayfield in Graves County who were jailed for refusing to display the bright orange reflectors on the backs of their buggies (Anderson 2014) and from which the recent legislation emerged. In general, the Swartzentruber Amish also prohibit indoors bathrooms, central heating, window blinds, gas run refrigerators (literally, ice boxes only), and linoleum floors, and in general, technologies that even other Amish from the Old Order would use (Hurst and McConnell 2010).

In regards to the other Amish trajectory considered here, the more progressive Amish at the time of the great division in the 1860s were influenced by Protestant evangelicalism: these so-called Amish-Mennonites developed formal religious institutions, shifted religiosity from tangible practices to abstract theology, and relocated authority from informal community-based sources to codified, legalistic modes (Hostetler 1992; Cronk 1981). They eventually merged with progressive factions of Mennonites, which themselves divided with Old Order Mennonites. Around 1910 another Amish-Mennonite group broke from the Old Orders, embraced Protestant evangelicalism, and, over the next 100 years, assimilated into society (Yoder 2014).

However, another division gradually emerged from 1910 through the early 1960s. This 
"Beachy” Amish-Mennonite movement (named for an influential bishop) constituted a third exodus from the Old Orders. While originally desiring technological conveniences like automobiles and electricity, most Beachys also came to accept evangelical Protestantism. But, they still identified as Amish. Today, the Beachy movement has birthed six sub-affiliations (and several other unorganized networks) based on the extent to which each network of churches wishes to distance itself from total assimilation into the mainstream. Today, Kentucky has more diversity in Amish-Mennonite subgroups (six) than any other state. It follows Pennsylvania, Ohio, and Indiana in having the most Amish-Mennonite churches, members, and adherents (Anderson 2012a).

\section{Population Growth and Community Expansion}

Three factors have converged to increase the Amish population and subsequent community expansion, both in Kentucky and throughout North America. First, as America turned away from the nineteenth century and faced the great changes that would transform its economy, culture, and society in the twentieth century, the distance between the Amish and the mainstream grew. Concomitantly, the rate of retention of sons and daughters in the faith, once they reached the age of decision, steadily increased, especially in the latter half of the twentieth century (Greksa and Korbin 2001; Hickey 2011).

Second, Amish families remained quite large (Markle and Pasco 1977; Ericksen, et al. 1979; Wasao and Donnermeyer 1996) despite their shift out of farming (Kreps, Donnermeyer and Kreps 1994). Children are considered "blessings from God" and artificial means of birth control violates the church discipline. Children help with the chores necessary to run a farm or a non-farm business. Today, it is estimated that $80 \%$ to $90 \%$ of children born to families in the Old Orders decide to be baptized and abide by the Ordnung (Greska and Korbin 2002). Soon after marriage, family formation begins, and a new generation continues to expand the population (Hostetler 1993, 172; Stevick 2007). Amish-Mennonite births have also remained high, though evidence some decline since the 1990s (Anderson 2013b).

Finally, a third factor is the growing diversity of both the Old Orders and AmishMennonites. As described earlier, many of the twentieth century schisms from the post-1860s Old Order Amish remained internal, hence, retaining an Amish identity despite differences large enough to spur the development of new affiliations or fellowships.

This extraordinary rate of successful socialization as exemplified by high baptism rates, coupled with large families and internal divisions, has created both a population boom and a settlement boom, especially over the past six-plus decades. It is estimated that the population of the Amish groups from the Old Orders today is doubling every 20 to 25 years, and in response, so are the number of new communities or settlements (Donnermeyer and Cooksey 2010). For example, the number of Amish settlements who remain dependent on the horse and buggy was 66 in 1959, 150 in 1979, 296 in 1999, and 483 as of October 31, 2014. It is estimated that a new 
community is begun somewhere in Canada or the Unites States every four weeks (Donnermeyer and Cooksey 2010). The Amish-Mennonite population is increasing as well, growing from 36 churches in 1959 to about 286 as of October 31, 2014. ${ }^{4}$

Three major religious motivations_-based on Anderson (2012b)_-are discernible for Old Order and Amish-Mennonite migration. First, they seek social/spatial/economic/political contexts that better support pursuit of their religious ideals. For example, some seek less crowded areas away from large settlements, which overflow not only with tourist development but also with plain Anabaptists. Others seek locations where they can maintain farming as their economic base, as the availability of farms and the price of land makes staking a claim for the next generation of families difficult in the more crowded settlements or urbanized areas (Luthy 1994, 244-45; Smith 2013).

Second, they are following a religious command that requires migration. For example, some new communities begin as a mission or outreach community (see Van Kampen (2009) and Gaetz (1994) for examples), driven by Jesus’ Great Commission in the New Testament’s Gospel of Matthew, Chapter 28. These largely arise from the evangelically minded Amish-Mennonites and New Order Amish (Anderson 2012b; Matthews 2001; Nolt and Meyers 2007).

Third, they are seeking to escape places where they face competition with other (often similar) religious groups or even competing ideologies within their very group. Some communities begin because a small network of households (related through either family or friendship ties, or both) are dissatisfied or disagree with the Ordnung of their church districts, and seek to establish a community where new rules can be established without competition (Luthy 1994, 244; Schwieder and Schwieder 1976). Some also migrate when differences cause a division and the withdrawing party opts to remain in the community. Yet others are unhappy with levels of tolerance in the community for the behavior of teenagers and seek a new place where greater social control can be exercised (Nolt and Meyers 2007; Stevick 2007).

Regardless of the motives, understanding migration among the Amish requires appreciation of the much more collective or communal nature of their geographic mobility. Individual families must resettle in an area where they can participate in the church and community-based activities. Often, sets of families from the same or several settlements coordinate their relocation to a new locality, all arriving within a few months of each other (Donnermeyer and Cooksey 2010).

\section{Amish Population Growth and Community Formation in Kentucky}

Most of the increase in Amish settlements remains in their historic homelands of the Midwest, but expansion in the southern and western regions of the United States is also taking place. Landing (1970) called attention to the absence of Old Order Amish settlements in the U.S. South, which, at the time he wrote, consisted of a few mostly unsuccessful attempts. While the Amish had made a handful of attempts to settle the region from the end of the Civil War on 
(Crowley 1978), most settlements met extinction after only several years (see Luthy (1986) for detailed accounts of these settlements). The movement of the Old Order groups to a southern state goes back to attempts to create communities in Dickson County, Tennessee (Yoder 1991, 248) and Monroe County, Mississippi (Luthy 1986, 221) in the 1890s. Both failed, in part because they were too far away from other Old Orders (Luthy 1997, 8-10). Even today, the Old Orders have been less able to plant permanent settlements in many regions of the South, despite rapid growth into regions of Midwestern states in which the Old Orders have never gone before, such as Minnesota and Nebraska. Kentucky is the exception, bordering large Amish populations in Ohio and Indiana. Missouri, bordering both Illinois and Iowa, also has 39 settlements, and can be considered a second Southern (albeit "border”) state where the Old Orders have a sizeable presence. Kentucky and Missouri aside, nearly one third of new Southern settlements attempted by the Old Orders since 1990 did not succeed and became extinct, which is a much higher rate of failure than can be found in any other region of North America (Donnermeyer and Cooksey 2010).

While this picture looks bleak for settlements of Old Orders in the U.S. South, Landing's (1970) analysis did not differentiate between settlements of the Old Orders and those of the Amish-Mennonites; had he accounted for this, he would have found that the latter settlements, though a minority of attempts, were all well established and thriving. Further, many of the socalled "failed" attempts of the Old Orders were those who decided to get automobiles and join a Beachy group.

One of the most successful "failures" for the Old Orders was the Virginia Beach, VA, settlement, to which Kentucky has many links, though largely indirectly. Through the 1930s, the church was increasingly enveloped in volatile Ordnung syntheses, including an allowance to drive automobiles if for business purposes (specifically, a dairy plant) but not personally own them (but the business could own them). In 1940, a Beachy Amish-Mennonite faction withdrew from the Old Orders and accepted personal automobile ownership. The families who adhered to a stricter view of automobiles migrated to Stuarts Draft in Virginia's Shenandoah Valley in search of isolation from Amish-Mennonite influences. While they banned driver's licenses, they accepted farm tractors for field work and home electricity off the grid. Further, they carried on a practice first established in the Somerset County, PA, Amish settlement in the late 1800s from which many trace their roots: worship in meetinghouses (Beachy 1954). Despite these variances with most other Old Orders, they retained a strict standard of adolescent behavior, modest dress, and ritual procedure.

As urbanization overtook the Beachy church in Virginia Beach during and after World War II, they sought more rural locations, especially to continue farming. Four groups migrated to different remote regions of the South, including Franklin, KY, in 1968. In the decades thereafter, this church grew, directly and indirectly birthing five additional Amish-Mennonites churches throughout the Commonwealth and one local unaffiliated conservative Mennonite church, which superficially selected this alternative identity given the already saturated presence of Beachy 
churches in the community (three).

The more conservative families who migrated from Virginia Beach to Stuarts Draft, VA, in 1942 again faced a Beachy division. In 1954, many families withdrew from the Old Order, seeking diverse objectives, and started a Beachy church in the community. Ever seeking a single affiliation settlement, most of the remaining Old Order families migrated in 1958 to Todd County, near the town of Guthrie (Luthy 2009, 12). When the New Order Amish started in Ohio in the 1960s, the Guthrie community loosely associated with the New Order movement, though never fully fellowshipping with the Holmes County New Orders in part because of the Guthrie settlement's acceptance of grid electric and meetinghouses. However, in regard to grooming and garments, the Guthrie Amish are today one of the most conservative settlements in the New Order Amish affiliation, having migrated twice to escape progressive tendencies (Waldrep 2008).

Meanwhile, in Stuarts Draft, Virginia, the new Beachy church almost immediately faced strife. On the one hand, some families sought an aggressive evangelization program that included some lenience in dress restrictions, the elimination of German from church services, and churchsponsored community outreach programs. Other members, in joining the Beachy church, just wanted automobiles and telephones, hoping to retain nearly all other distinctive of the Old Orders. The first division, in 1957, resulted in the withdrawal of the most evangelistic members, who agreed to relocate several counties to the northeast. Yet, in 1968, a second group withdrew, establishing a more lenient Beachy church in Stuarts Draft. The stricter Beachy families sought isolation from their progressive neighbors, and thus the majority of the Mt. Zion church members migrated from Stuarts Draft to Paris, TN, in the early 1970s.

Yet, even after this migration, a progressive element arose. In Paris, TN, in the 1980s, a small faction withdrew, and in several years the faction itself divided, leaving two relatively lenient churches next to two districts of what by now were the strictest Beachy churches in the affiliation. Because of the presence of more permissive Beachy churches in the same community, those from the original group again migrated, this time to new locations in Kentucky and Illinois.

These Beachy churches are today the most conservative in the Beachy movement, even retaining German in their church services. To distinguish themselves from the mainstream Beachy churches, they have adopted the name "Midwest Beachy.” Today, Midwest Beachy churches are located in Casey, Graves, and Webster Counties. In addition to dress standards as strict as or stricter than many Old Order Amish, they require black automobiles and would proscribe microwaves and answering machines. Two Berea Amish-Mennonite churches (one recently re-affiliating to the Ambassadors Amish-Mennonites), the second most conservative Amish-Mennonite subgroup, also trace their origins to Paris, TN.

In the example of the Guthrie Amish and those Beachys from Paris, TN, the multiple migrations strengthened the ideological stance of the final settlements by filtering out "freeriders," those with weaker commitments (Iannaccone 1994). First, those not devoted to the strict 
conservatism withdrew and started another church. Second, those who were conservative but not committed to it to the extent that they were willing to migrate were filtered out from the new settlement. Committing to a conservative identity self-perpetuates itself, as individuals and families attracted to this orientation move to the community from other churches, reinforcing the ideology.

Growth of communities for both the Old Orders and Amish-Mennonites in Kentucky was at first slow. The 1960s and 1970s saw the founding of four Old Order and three AmishMennonite settlements in Kentucky. Starting in the 1980s, however, a settlement boom came to Kentucky. Seven settlements from various Old Order affiliations were founded during that decade, followed by 11 during the 1990s, 12 during the first decade of this century, and already another 11 established between January 1, 2010 and October 31, 2014. Three from the various Amish-Mennonite affiliations started up in the 1980s, five during the 1990s, four in the first decade of the twentieth century, and one more since 2010. Altogether, the Old Orders and AmishMennonites made 61 new community attempts, of which eight have failed. Of the failures, seven were attempts by Old Orders. One Amish-Mennonite attempt lasted only two years and existed in the midst of an already bustling Amish-Mennonite settlement (see Table 1 in the appendix).

The earliest Amish communities in Kentucky were founded by families from settlements to the east, such as from Delaware, Pennsylvania, and Virginia, and north from Ohio. The exception is Crofton, which originated with families from Mountain View, Missouri. Also, of special note are the conservative Swartzentruber settlements of Park City / Smith’s Grove, Sonora, and Mayfield, which were started by families from Ethridge, Tennessee (also Swartzentruber). In the case of the Sonora settlement, some of the original families also came from a Swartzentruber community in the upstate county of Heuvelton, New York. In turn, the Leitchfield Swartzentruber community was begun in 2011 from families out of the Park City / Smith's Grove settlement.

Many of first families for settlements founded since 1990 are from Indiana and Michigan, along with Ohio and Pennsylvania. As well, stateside communities are the origin for new settlements elsewhere in the state. Of special note is the extinct community of Gradyville, whose families dispersed to many places, including Crab Orchard and Lewisburg, and it is families from Crab Orchard who founded the Hawesville community in 2011.

The maps show how rapidly the rural landscape of Kentucky has changed with the arrival of Amish (Figure 1). In 1980, there were only a few scattered communities, but now, Amish communities are interspersed throughout the state, skirting around the more urbanized areas and extreme topographical variation (Figure 2), as well as places where the price of land makes relocation there unreasonable, such as the Blue Grass Region. At the time of their founding, only five communities were in counties defined by the U.S. Census Bureau as metropolitan, including Pleasureville, founded in 2013 in Henry County. In all five cases, however, the counties remain largely rural in flavor but are tied to a larger, more urban county through commuting patterns. ${ }^{5}$ 


\section{Figure 1: Extant Amish Communities in Kentucky}
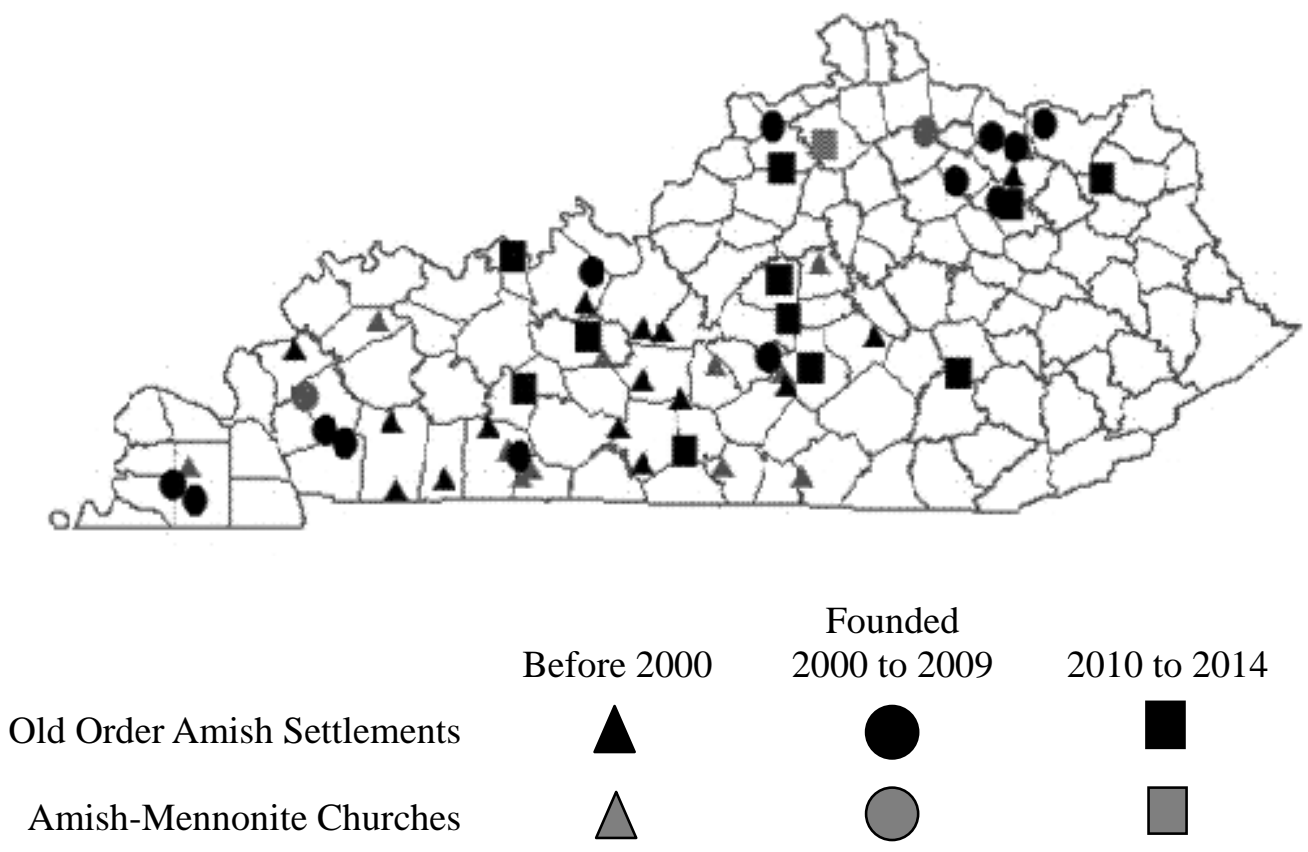

The largest population for a Kentucky county in which an Amish settlement is located today is Warren County (county seat, Bowling Green), with a 2010 population of nearly 114,000. Only one other host county is larger than 100,000, namely, Hardin County (county seat, Elizabethtown). The average size of a host county to an Amish community was about 22,800 persons, and a population density of 53.7 persons per square mile. This population density is exactly half the state's 2010 population density (107.4).

Altogether, we estimate the Kentucky population of Old Orders and Amish-Mennonites at $9,834,{ }^{6}$ which is only $0.224 \%$ of the total population (based on 2013 population projections for Kentucky), but belies the significance of their presence in Kentucky. Forty-five counties (37.5\% of all Commonwealth counties) play host to all or part of at least one Amish community. Grayson has the most communities, with four, but they represent only $1.064 \%$ of the population.

Of all the Amish in Kentucky, nearly five in six (83.0\%) are Old Orders. The most populous Amish county is Hart County, the site for all but a few families in the largest of all Amish communities, Munfordville / Horse Cave, and about half of the smaller community of Hardyville / Three Springs. Both are from Old Order affiliations. Hart County is also the most Amish county in Kentucky, with about 9.3\% of its 18,000-plus population belonging to an Amish community. The next closest county is Crittenden, which is about $6.6 \%$ Amish, and includes two Old Order communities: Marion and part of the Salem settlement. Fleming County is nearly 5\% Amish due to hosting a small settlement with an Old Order and Amish-Mennonite church (Flemingsburg) and another single affiliation settlement across the county (Hillsboro) (see Appendix). 


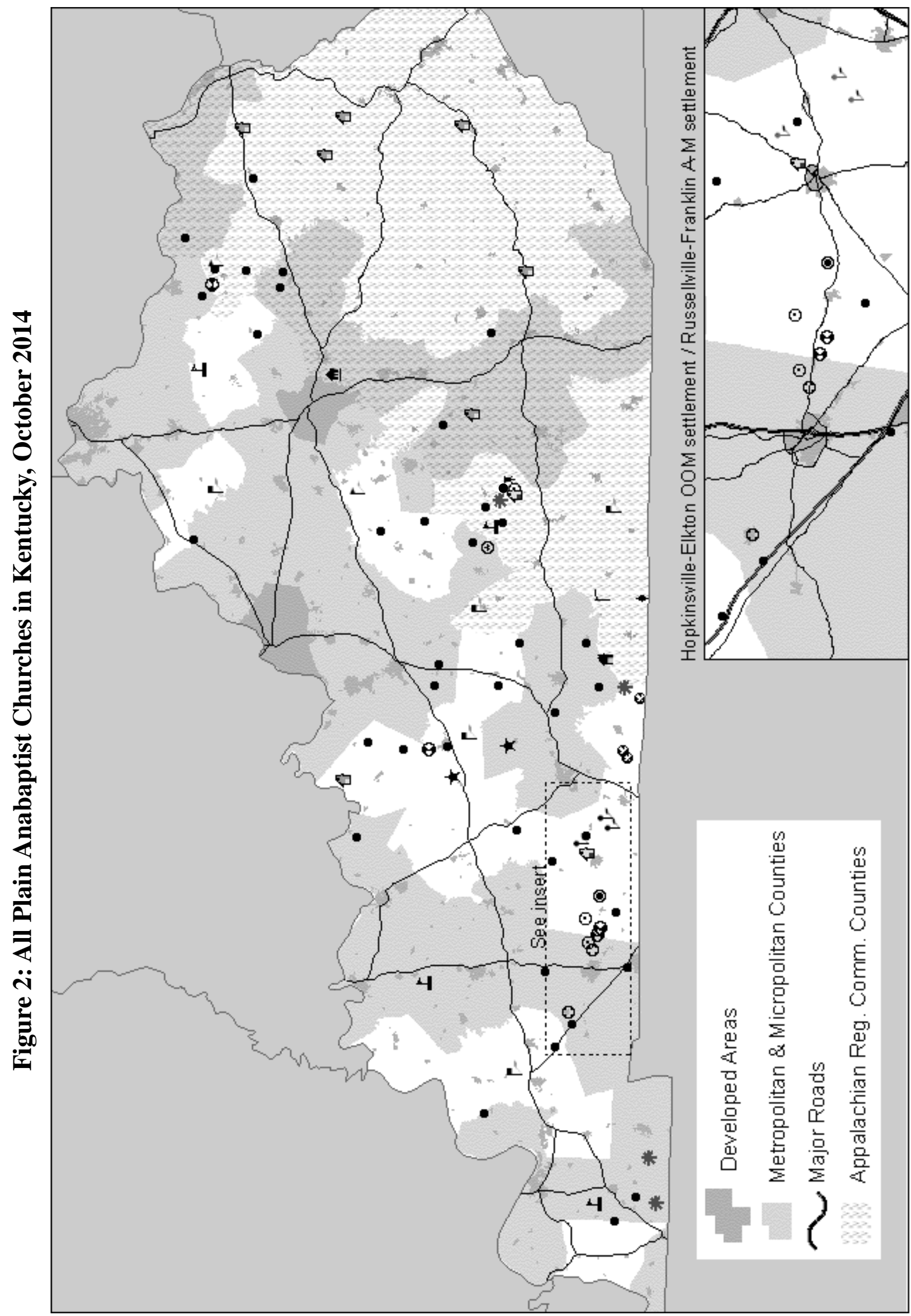




\section{Figure 2 (con’t): Affiliations}

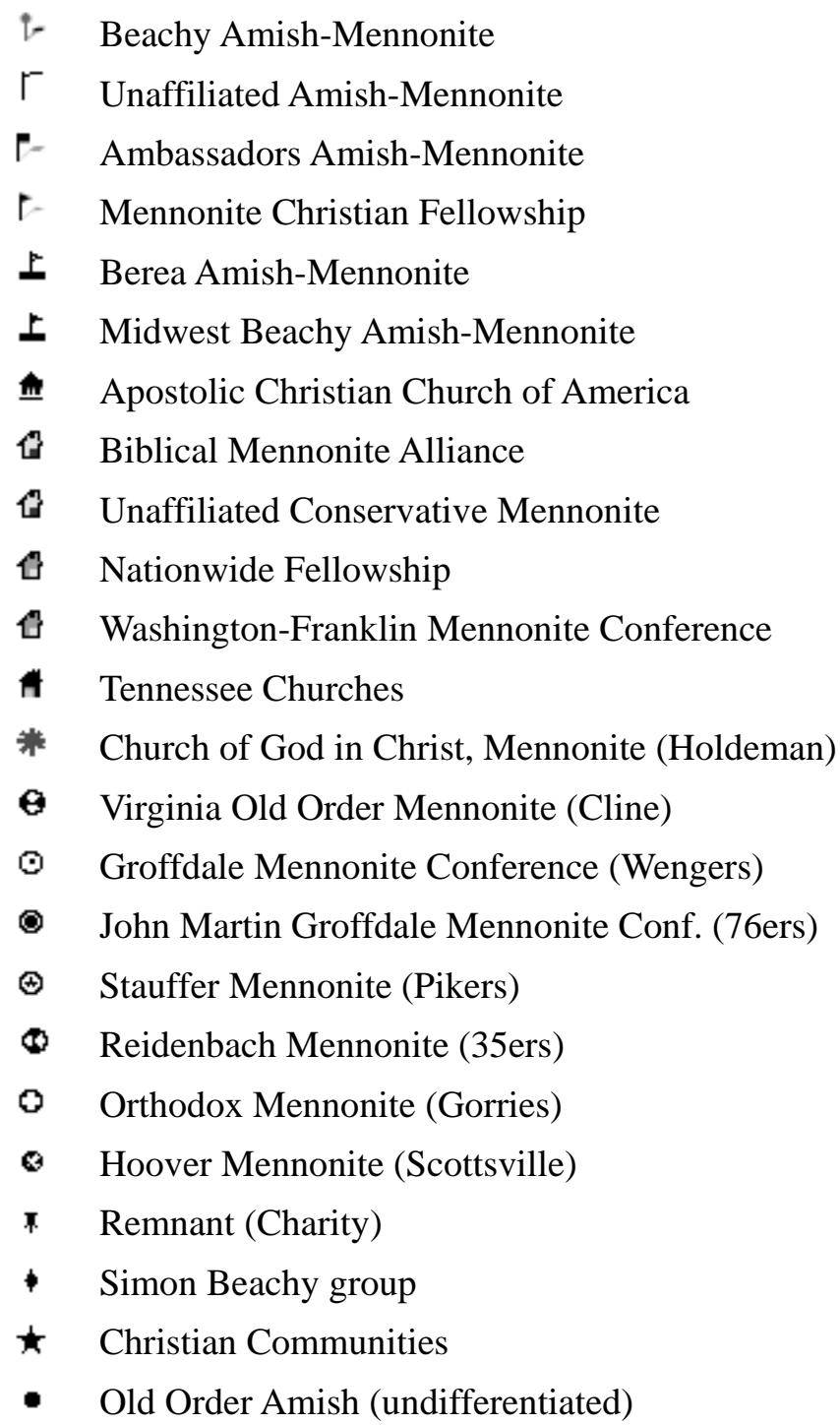

One aspect of site selection illustrates why both Amish groups are not located in the deeper reaches of eastern Kentucky: it is located to the east of the Daniel Boone National Forest. As Meyers and Nolt (2005, 35-39) and Donnermeyer and Cooksey (2010, 197-98) note, access to services mostly found in towns and cities are important considerations. These may include a post office, grocery store, doctor, dentist, and other services that today can still be found in communities as small as 5,000, despite the continuing consolidation of retail and professional services in rural America. Further, for Old Orders, the terrain of many counties in eastern Kentucky would make buggy driving and sharing the road with cars and trucks difficult. For Amish-Mennonites, commercial agriculture remains an important vocation, which is not well suited to the mountainous extremes of the east. Of those who have left agriculture, a nearby market is important for common employment forms such as trades or retail stores. And for both 
groups, whether via automobile ownership or taxi, for a people on the move-visiting this other settlement and that other settlement - when it comes right down to it, the long, windy roads are just tediously nauseating to travel often.

The founding of a new settlement requires careful logistical planning, because it involves moves by multiple families, not individual families (Anderson 2012b), and requires a reproduction of social organization and cultural practices based on religious beliefs and heritage, in essence, carving out a new ethno-religious enclave (Kent and Neugebauer 1990). A new area must be scouted out, which is usually accomplished by a group of men (called a "land party") working from information provided by Amish in nearby communities and by local real estate agents. Enough parcels of land must be found for a critical mass of families to move in so that a viable church group can be established, religious services can be conducted, and their own church leaders can be selected (Donnermeyer and Cooksey 2010, 196-98). Fortunately, for the Amish, the decline of the American farm population and a host of other factors have created favorable economic conditions in many rural regions.

In Kentucky, many opportunities came about by the tobacco buy-out program, just as the dairy buy-out spurred the expansion of Amish settlements into Wisconsin during the 1980s and 1990s (Cross 2004, 83-85). A reporter from the Mays Lick settlement in Mason County recounted in The Budget: ${ }^{7}$

We had some families here in the middle of the week looking for farms, with offers made. Seems like we have a lot of old time tobacco farmers in our area and now that the tobacco buy-out was signed by our President on October 24, 2004, there is a little panic going on which makes for a few more farms for sale. (February 16, 2004, 10)

Another reporter, this time from the settlement of Irvington in Breckinridge County, sent a note to The Budget with the following description of the local area:

Real estate keeps coming up for sale in the area. Last week an elderly lady stopped at Willie Detweilers' to say she would like to sell her 430 acre farm to our people. She said to keep it hush as she only wants to sell to the Amish. It is only 2 miles away.

Founded in 1998, the Lewisburg settlement in Logan County, started by families from the now extinct Gradyville settlement, shows the highly cooperative nature of establishing new communities. One Amishman bought five hundred and seventy acres, which was then divided up so that 10 families could live there. The land transfer occurred in May, and by September the actual relocation of families commenced. The first church services were held in October, and the first communion service in November. Today, Lewisburg has grown to over 50 families with the purchase of additional land, and has about 250 people. As well, the original church district became so large it divided into two (Miller 2004, 52).

Problematic for the Old Orders is the possibility of conflicts with local authorities over 
ordinances related to septic systems, zoning, building permits (Bennett 2003; Testa 1992), buggy markings (Anderson 2014; Zook 2003), and other issues, as the recent case from Mayfield illustrates. Although some of these are based on religious tenets and the Ordnung of a church district within a specific settlement, others are simply a matter of convenience and a desire among Amish landowners to do with their land what they want. For example, a reporter from the Irvington community in The Budget admits that:

One reason for picking this area for a community was because of the lack of zoning and regulations for residential buildings/home businesses. However, for the counties with no zoning, the state has some regulations regarding the construction of a business building itself to assure public safety. Our meeting with our representative soon brought results, as the next day I had a call from the state building office in Frankfort who assured me they are not here to make it rough but to work with us. (October 26, 2005, 33)

Three of the more recently established Old Order communities in Kentucky illustrate how fast an Amish settlement can grow, and with a critical number of families comes sustainability. For example, Caneyville (Grayson County) was founded in 2010, with the first families moving there from the southern Illinois settlement of Belle Rive / Opdyke in September. By the first month of 2012, 12 families had relocated there, not only from Belle Rive / Opdyke, but other settlements in Kentucky, Michigan, and Ontario. ${ }^{8}$ Owingsvlle’s (Bath County) growth is even more dramatic, with 17 families moving there between August 2010 and April 2012. These families came from a variety of other Amish settlements in Indiana, Michigan, and Pennsylvania. Finally, Leitchfield, also in Grayson County, began in early 2011 and now has 12 families, all of whom came from the Swartzentruber settlement of Park City/Smith’s Grove. Past studies suggest that Amish coming from diverse origins may have difficulty reconciling competing Ordnungs (Hartman 1986; Johnson-Weiner 2010), threatening survival, and such a possibility remains to be seen for these rapidly growing communities of diverse backgrounds.

A major driver of Amish-Mennonite church growth is the desire to establish new congregations in areas without other plain Anabaptist churches. This vision accomplishes two goals: it prevents the home community from growing too large, and thus harboring factions, and it serves as a vehicle for the Amish-Mennonites to engage the community and make their church available to religious seekers. The Ambassadors Amish-Mennonite subgroup has instituted this program by logging a statement in their written church standard, that when the church "is financially able, has sufficient membership, and senses God's leading and 'open doors,' a plan would be initiated by the home ministry to plant a new church in another area.” Since its establishment in 1993, the Cedar Springs Amish-Mennonite church of Leitchfield, itself a church planting from a Beachy church in the Russellville-Franklin settlement, established new churches in 1999 (Summersville, KY), 2003 (Advance, MO), and 2011 (Owenton, KY). The Summersville church also established a new congregation in Lexington, IN, in 2008. With such rapid successive church planting efforts and continued growth in their ranks, Kentucky will likely host further Ambassadors Amish-Mennonite churches in the future. Several other churches 
are also the direct product of this church planting vision, including Mercer County's Mennonite Christian Fellowship church (from Flemingsburg) and Cynthiana’s Berea Amish-Mennonite church (from Monticello).

\section{Old Order Mennonites and Other Plain Anabaptists in Kentucky}

Old Order Amish and Amish-Mennonite groups are not the only plain Anabaptists that have been attracted to Kentucky. The Commonwealth has experienced a notable upswing in two other groups: churches from strict conservative Mennonite affiliations (Categories D and E in the Appendix of Anderson 2013a) and churches from eight different horse and buggy-based Old Order Mennonite affiliations, numbering more than any other state, Pennsylvania excepting. A third movement has also seen modest growth. Kentucky, along with Tennessee, has also enveloped a set of experimental, intentional communities, which emphasize strict standards of technology and dress, yet attempt to realize their faith within rationalized means. What threads these communities is that, at their core, the answer, "That's just how we do it / That's how it has always been done," to the question, "Why do you do $x$ ?" is insufficient and is inferior to a selfreflective, deductive reply. You must know why you do what you do. Beyond these three groupings, other miscellaneous plain churches dot Kentucky’s countryside. All-in-all, 33 congregations from non-Amish plain Anabaptist religious traditions dot Kentucky's countryside (see Figure 2 and Appendix Table 3).

Whereas the Amish groups are located largely in central and western Kentucky, the conservative Mennonites are scattered across the eastern Appalachian region. These churches have arisen from cross-spectrum missionary efforts among Mennonites, both conservative and mainstream (the latter not tracked here), to the relatively isolated mountain regions of Appalachia. Four Nationwide Fellowship churches and two Washington County-Franklin County Mennonite Conference churches are in single church settlements of eastern Kentucky. The first of these was established in 1959-60 in Crockett, KY, by Mennonites who recently withdrew from mainstream Mennonite bodies to observe continuity in distinctive Mennonite identity. There they established Rod \& Staff Publications, a flagship organization in the development of conservative Mennonite identity (Anderson and Anderson 2014). Washington-Franklin Conference established their first church in 1978 and operates it like a single settlement mission church, including holding services every Sunday (their congregations around Hagerstown, MD, would have off Sundays).

Old Order Mennonites, on the other hand, have followed the settlement patterns of Amish. The western Kentucky Trigg-Christian-Todd Counties settlement stretches along the eastwest US-68 corridor, from I-24 to Hopkinsville, past the community center of the village of Fairview with its towering Jefferson Davis Monument (a Southern replica of the Washington Monument), and ending about five miles east of Elkton. Groffdale Conference Mennonites (Wengers) from Pennsylvania started moving in in the 1980s, formally establishing their first congregation in 1991, then a second district in 2010. Simultaneous to the Groffdale migration, 
the Henry Hoover Reidenbach (35ers) faction (a 1985 branch off the John Martin 35ers, which itself was a faction from the largest and primary Reidenbach body) relocated in their entirety from Lancaster County, PA, to Fairview, KY, over the winter of 1989-90, seeking to escape the ever increasing congestion and development in southeastern Pennsylvania (Albertsen 1996). After several years, their leader, Henry Hoover, withdrew and sought affiliation with the Orthodox Mennonites of Ontario, an intentionalist minded, ultra-plain Old Order Mennonite body (see Martin 2003, 179-83). The Orthodox Mennonites in time developed two nuclei, one east and one west of Hopkinsville. The Reidenbach Mennonites continued to grow, being joined by a second congregation affiliated with the primary Reidenbach body. The most recent affiliation of Old Order Mennonites in the settlement is a group of "76ers" or the John Martin Groffdale subgroup, a faction off the Groffdale Mennonite Conference that did not approve of changes to the 1976 church order (specifically the ban on telephones in ministers' homes). The division occurred in Pennsylvania and Missouri in 1993 (Scott 1997). Several years later, a group from Missouri moved to Kentucky, differing with the Missouri group over the use of tractors for farming, though the two churches remain in formal fellowship.

Old Order Mennonites exist elsewhere in the state, including a recent, rare, out-of-state settlement attempt by Virginia Old Order Mennonites (Cline), and a persistently single-church sized Stauffer and Groffdale Old Order churches established in 1979 and 1987, respectively, in the Casey County plain Anabaptist settlement. The Groffdale group has been intentionally strict, but because Conference makes uniform regulations, could never enforce a stricter standard. Consequently, from 2013-14, two-thirds of the community moved out to start a stricter settlement in Tennessee, where they remain associated with Conference but have autonomy to establish a local standard, including restrictions on tractors, grid electric, and private telephones. Additionally, in 2007, the Lancaster County, PA, John Martin Reidenbach church divided once more, and the Daniel Hoover group, with the slight majority, relocated the entire church to Kentucky, settling around Leitchfield (see Hoover 2011 for one man's account of the division).

Kentucky and Tennessee has become notorious for picking up experimental plain Anabaptist churches. Among them was the Christian Community at Cookeville, a semicommunal, intentional community established by former Aylmer, ON, Amish bishop Elmo Stoll. He was joined by Old Order Mennonites, Amish, German Baptists, and non-plain background seekers, but the mix of influences and his sudden death in the late 1990s pushed the community to disband by 2001 (Pride 2003). Stoll's sons, replacement bishop (and former German Baptist) Bryce Geiser, and perhaps others, having returned to their root religious traditions, yet envisioned the re-establishment of the Christian Community, albeit with revisions. They established the Caneyville Christian Community in Kentucky in 2004, and several years later established a satellite community 30 miles away near Brownsville. True to their Christian Community roots, the movement has drawn a diversity of backgrounds to the enclaves, though at a milder pace. The group's temperament is intentionalist, non-traditional, and inventive, yet all within a rationalized discourse supporting their ritual procedures, doctrinal expositions, and strict 
technological, dress, and home décor standards.

Kentucky is also the home of an intentionally minded, yet technologically primitivist, Old Order Mennonite group known colloquially as the Hoover Mennonites or Scottsville, KY, churches. With provision for English in services but an Ordnung comparable to the strictest of horse-and-buggy Amish, these churches have attracted people from a variety of backgrounds, including both plain churches and non-plain, primitivist-oriented converts (Brende 2004). The movement had rocky roots. In Snyder County, PA (in the hills north of Harrisburg), the Stauffer Mennonites experienced a series of divisions from 1944 to 1949, whereby the nucleus withdrawing each time experienced a subsequent division. In the early 1950s, the nucleus that thrice withdrew, by now composed largely of Old Order Mennonite transplants from Lancaster County, merged with religiously intentional Swiss Amish in-migrants from the Reformed Amish Christian Church of Allen County, IN, and the Hohenwald, TN, Amish (originally from Adams County, IN). Additionally, they were joined by individual Russian Mennonites and Orthodox Mennonites. The group focused on simple, disciplined living within the context of revivalistic energy. Yet, withdrawal, outmigration, and factiousness concerning theological-doctrinal questions gnawed at the group, including a 1964 division in which the majority withdrew from the bishop's leadership. By 1978, those remaining committed to starting anew, and they migrated to Scottsville, KY, there being joined by prior co-adherents who had moved to Muddy Pond, TN (Hoover n/d). The community was a success, and today has two districts, a sister church 25 miles east in Holland, and other affiliated settlements in Tennessee, Missouri, Belize, and Ohio.

The remaining Kentuckian plain Anabaptists will be briefly noted. An additional intentionalist church, albeit with a lower strictness level than the Scottsville or Caneyville communities, exists in Hestand, KY, and is based on the "brokenness" emphasis of charismatic leader Simon Beachy, who emigrated in 1996 from the Believers in Christ church in Lobelville, TN (Waldrep 2008), itself an intentionalist community. The Holdeman Mennonites have four churches in Kentucky, the largest two being in the southwest. The pioneer church was established in 1989 and, with people moving in from all over, by 1991 was nearing 30 families. In the 2000s, a second district was started (Gospel Publishers and Koehn 1999). Among the Holdemans' congregations is a small church in the Casey County settlement, which also consists of Remnant (Charity) and B.M.A. (Biblical Mennonite Alliance) churches. Three churches, each advertising an alternative to Old Orderish "legalism" and "traditionalism," is suggestive of unrest at the Groffdale Mennonite church. The Mt. Hermon Mennonite church, wedged between the Scottsville and Hestand communities, is part of the "Tennessee churches," which, while an evangelical group, practices the strictest of standards among the automobile-owning conservative Mennonites, including regulations uncommon among conservatives pertaining to convenience technologies and employment/affluence. Finally, last and least, a fledgling Apostolic Christian congregation outside Lexington established in 1968 has seen gradual decline over the decades until, today, it counts its membership in the single digits (Klopfenstein 2008).

Certainly plain Anabaptists in Kentucky are not limited to Amish, as this subsection 
demonstrates, and certainly growth is not limited to the Amish either. As Kentucky has proven its satisfactory social, economic, and geographic environment for a variety of plain Anabaptist demands, the Commonwealth will continue to witness a rapid growth rate. What makes Kentucky stand out is its resilience to clearly defined, burgeoning settlements characteristic not just of historic states of plain Anabaptist settlement (e.g. Holmes County, Ohio or Harrisonburg, Virginia) but of states with only post-WWII modern plain Anabaptist settlements (e.g. the Finger Lakes settlement of New York or the Jamesport settlement of Missouri). The inclination among plain Anabaptists in Kentucky has thus far been toward single (or low sum) church settlements. The first Old Order Amish and Amish-Mennonites in Kentucky were seeking single church settlements, and this vision continues to motivate Southern plain Anabaptists today.

\section{Conclusion}

The history of the Amish is one of nearly constant movement (Crowley 1978). In Europe, they moved to avoid persecution and to seek rural places where they were protected by nobility who sought their expertise in agriculture. In the colonies and then Canada and the United States, they moved to find new places where they could build communities based on religious principles and practices. Moving has become part of Amish peoplehood and is built into their community repertoire of action when facing a new challenge (Reschly 2000).

Due to consistently high fertility, increasing rates of retention, and internal subdivisions that have allowed for greater differentiation of fellowships within the Amish, the past several decades have seen the Amish become one of the fastest growing subcultures in America. Their lifestyles compel them to seek out rural places to live and worship. While historically they have found non-urban niches in various states of the Midwest, plus Pennsylvania and New York, the Amish have also spread south, especially into Kentucky. Original families have come from all directions: Virginia, Delaware, Pennsylvania, Ohio, Michigan, Indiana, Missouri, and Tennessee

Nearly all Amish communities are in two parts of Kentucky, counties to the west of the Bluegrass region, and in more recent times, a cluster of counties in the northeast. The Amish presence in eastern and central Kentucky is impeded by either terrain or the price of land, or both; the former has not impeded conservative Mennonites who seek to establish a community witness in a non-Anabaptist area. Nonetheless, the tobacco buy-out has opened many opportunities for the establishment of more recent communities. Plus, older settlements in Kentucky are now the source for first families to several newer settlements within the state.

Accounts of how a location for a new settlement begins indicate little likelihood that Old Orders and Amish-Mennonites will begin community formation anytime soon in eastern Kentucky, despite attractive land prices. Distance from other Amish settlements, lack of community services, absence of agricultural land and nearby commercial markets, and / or steep terrain unfavorable to horse and buggy travel will constrain growth. Even the conservative Mennonites located there demonstrate their interest in accessibility by locating near major 
highways. Nonetheless, select valleys east of the Daniel Boone National Forest may attract settlers, as indicated by a new Old Order settlement of Annville / London. If Amish-Mennonites move to eastern Kentucky, it is only because of their evangelical drive to establish outreaches in places without plain Anabaptist churches. In turn, this may spur Old Orders to locate there, based on information exchange between extended family members whose networks span both subsets of Amish, as well as the infrastructure Amish-Mennonites provide (e.g. bulk food stores, taxi service, and labor-based employment opportunities). A case like this has occurred in Virginia, where an Old Order Amish community was recently established near Rose Hill in Virginia's most western county, Lee, where an Amish-Mennonite congregation was already located.

There are 53 extant Amish communities in Kentucky today. Of those, nearly half were founded in the first 14 years of this new century. If this growth is predictive of rural Kentucky's future, there will be 60-plus communities by 2020, and about 80 and perhaps as many as 100 settlements by 2030. As land availability in historic Amish homelands declines, growth in states of the mid-south, like Kentucky and Missouri, could accelerate. Their impact in some counties will be substantial, affecting not only economic development and population trends, but the social and cultural make-up of these areas, and the relationship of local government to groups who do things differently based on their religious beliefs.

\section{Endnotes}

${ }^{1}$ Contact information: Joseph F. Donnermeyer, Professor Emeritus, School of Environment and Natural Resources, The Ohio State University, Columbus, Ohio 43210; donnermeyer.1@gmail.com; 614-582-4710.

${ }^{2}$ We acknowledge and appreciate the archival resources available to us at the Heritage Historical Library, Aylmer, Ontario.

${ }^{3}$ Generally, the name of an Amish community is based on a nearby place name. Most of the time, this place name is the nearest community with a post office.

${ }^{4}$ This number includes international churches and excludes two unaffiliated and 20 Tampico Amish-Mennonite churches, whose lineage descends from the Amish-Mennonites of the 1860s division and not the twentieth century Beachy Amish-Mennonite movement.

${ }^{5}$ Including the settlements of Hopkinsville / Pembroke (which spans parts of Christian, Logan and Trigg Counties in KY, and the northern edge of Montgomery County, TN), the Swartzentruber community of Sonora (Larue), plus Cadiz (Trigg) and Hawsville (Hancock).

${ }^{6}$ A detailed description of the methodology necessary to develop county-level estimates of the Amish population is available in Donnermeyer, Anderson, and Cooksey (2013).

${ }^{7}$ The Budget is a newspaper published in Sugarcreek, Ohio, which includes reports from hundreds of Amish settlements. See Galindo (1994) for a literary description. 


\section{References}

Albertsen, Karsten-Gerhard. 1996. The History \& Life of the Reidenbach Mennonites (Thirty Fivers). Schobüllhuus, Schleswig-Holstein, Germany: Karsten-Gerhard Albertsen.

Anderson, Cory. 2012a. The Amish-Mennonites of North America: A Portrait of Our People. Medina, NY: Ridgeway Publishers.

Anderson, Cory. 2012b. "Religiously Motivated Migration.” Presented at the annual conference of the Association of the Sociology of Religion. Denver, CO.

Anderson, Cory. 2013a. "Who Are the Plain Anabaptists? What Are the Plain Anabaptists?" Journal of Amish and Plain Anabaptist Studies 1(1):26-71.

Anderson, Cory. 2013b. "Declining Birthrates among the Beachy Amish-Mennonites: An Indicator of Assimilation?” Presented at the annual conference of the Society for the Scientific Study of Religion. Boston, MA.

Anderson, Cory. 2014. "Horse and Buggy Crash Study II: Overstretching the Slow-Moving Vehicle Emblem's Abilities: Lessons from the Swartzentruber Amish.” Journal of Amish and Plain Anabaptist Studies 2(1):100-15.

Anderson, Cory, and Joseph Donnermeyer. 2013. “Where Are the Plain Anabaptists?” Journal of Amish and Plain Anabaptist Studies 1(1):1-25.

Anderson, Jennifer, and Cory Anderson. 2014. "Conservative Mennonite Storybooks and the Construction of Evangelical Separatism.” Journal of Amish and Plain Anabaptist Studies 2(2):245-77.

Associated Press. 2012 (March 23). “Amish Buggy Legislation Wins Final Passage in Kentucky.” Accessed Jan. 8, 2014 (huffingtonpost.com/2012/03/28/amish-bugglegislation-final-passage-kentucky).

Beachy, Alvin. 1954. “The Amish Settlement in Somerset County, Pennsylvania.” Mennonite Quarterly Review 28(4):263-92.

Beachy, Leroy. 2011. Unser Leit: The Story of the Amish. Millersburg, OH: Goodly Heritage.

Bennett, Edward. 2003. "Emancipatory Responses to Oppression: The Template of Land-Use Planning and the Old Order Amish of Ontario.” American Journal of Community Psychology 31(1/20):157-171.

Berger, Peter, Brigitte Berger, and Hansfried Kellner. 1973. The Homeless Mind: Modernization and Consciousness. New York, NY: Penguin. 
Brende, Eric. 2004. Better Off: Flipping the Switch on Technology. New York, NY: HarperCollins.

Cong, Dachang. 1992. “Amish Factionalism and Technological Change: A Case Study of Kerosene Refrigerators and Conservatism.” Ethnology 31(3):205-14.

Conkin, P.K. 1997. American Originals: Homemade Varieties of Christianity. Chapel Hill, NC: The University of North Carolina Press.

Cooksey, Elizabeth, and Joseph Donnermeyer. 2013. “A Peculiar People Revisited: Demographic Foundations of the Iowa Amish in the 21st Century.” Journal of Amish and Plain Anabaptist Studies 1(1):110-26.

Cronk, Sandra. 1981. "Gelassenheit: The Rites of the Redemptive Process in Old Order Amish and Old Order Mennonite Communities.” Mennonite Quarterly Review 55(1):5-44.

Cross, John. 2004. “Expansion of Amish Dairy Farming in Wisconsin.” Journal of Cultural Geography 21(2):77-101.

Crowley, William. 1978. “Old Order Amish Settlement: Diffusion and Growth.” Annals of the Association of American Geographers 68(2):249-64.

Donnermeyer, Joseph, Cory Anderson, and Elizabeth Cooksey. 2013. "The Amish Population: Estimates and Settlement Patterns.” Journal of Amish and Plain Anabaptist Studies 1(1):72-109.

Donnermeyer, Joseph, and Elizabeth Cooksey 2010. “On the Recent Growth of New Amish Settlements.” Mennonite Quarterly Review 84(2):181-206.

Donnermeyer, Joseph, and David Luthy. 2013. “Amish Settlements across America: 2013.” Journal of Amish and Plain Anabaptist Studies 1(2):106-29.

Emerson, Michael, and David Hartman. 2006. “The Rise of Religion Fundamentalism.” Annual Review of Sociology 32:127-44.

Enninger, Werner. 1988. “Coping with Modernity: Instrumentally and Symbolically, with a Glimpse at the Old Order Amish.” Brethren Life and Thought 33(Summer):154-70.

Ericksen, Julia, Eugene Ericksen, John Hostetler, and Gertrude Huntington. 1979. "Fertility Patterns and Trends among the Old Order Amish.” Population Studies 33(July):255-76.

Gaetz, Susan. 1994. Understanding Mennonitism: A Visual Ethnography of the Beachy Amish Mennonites of Lott, Texas. M.A. thesis. Austin, TX: University of Texas at Austin.

Galindo, René. 1994. “Amish Newsletters in The Budget: A Genre Study of Written Communication.” Language in Society 23(1):77-105. 
Giddens, Anthony, and Christopher Pierson. 1998. Conversations with Anthony Giddens: Making Sense of Modernity. Stanford, CA: Stanford University Press.

Gospel Publishers (Church of God in Christ, Mennonite), and Reuben Koehn (ed.). 1999. Histories of the Congregations [Third edition]. Moundridge, KS: Gospel Publishers.

Grammich, Clifford, Kirk Hadaway, Richard Houseal, Dale Jones, Alexei Krindatch, Richie Stanley, and Richard Taylor. 2012. 2010 U.S. Religion Census: Religious Congregations and Membership Survey. Kansas City, MO: Association of Statisticians of American Religious Bodies.

Greksa, Lawrence, and Jill Korbin. 2002. "Key Decisions in the Lives of the Old Order Amish: Joining the Church and Migrating to Another Settlement.” Mennonite Quarterly Review 76(4):373-98.

Hartman, Joel. 1986. “Old Order Amish and Old Order Mennonites in Missouri.” Pp. 140-57 in The German-American Experience in Missouri, edited by Howard Wight and James Goodrich. Columbia, MO: University of Missouri-Columbia.

Hickey, Damon. 2011. "The Retention of Young People by the Quakers and the Amish.” Quaker Theology 10(1):27-34.

Hoover, Mark Z. 2011. The Inside Story. Leitchfield, KY: Mark Z. Hoover.

Hoover, Peter. n/d. The Pure Church Movement. Working paper.

Hostetler, Beulah. 1992. "The Formation of the Old Orders.” Mennonite Quarterly Review 66(1):5-25.

Hostetler, John. 1993. Amish Society. Baltimore, MD: Johns Hopkins University Press.

Hurst, Charles, and David McConnell. 2010. An Amish Paradox: Diversity and Change in the World's Largest Amish Community. Baltimore, MD: Johns Hopkins University Press.

Iannaccone, Lee. 1994. “Why Strict Churches Are Strong.” American Journal of Sociology 99(5):1180-1211.

Johnson-Weiner, Karen. 2010. New York Amish: Life in the Plain Communities of the Empire State. Ithaca, NY: Cornell University Press.

Kent, Robert, and Randall Neugebauer. 1990. "Identification of Ethnic Settlement Regions: Amish-Mennonites in Ohio.” Rural Sociology 55(3):425-41.

Kreps, George, Joseph Donnermeyer, and Marty Kreps. 1994. "The Changing Occupational Structure of Amish Males.” Rural Sociology 59(4):708-19. 
Klopfenstein, Perry. 2008. Marching to Zion: A History of the Apostolic Christian Church of America. The Apostolic Christian Church of America.

Kraybill, Donald. 1989. The Riddle of Amish Culture. Baltimore, MD: Johns Hopkins University Press.

Landing, James. 1970. “The Failure of Amish Settlements in the Southeastern United States: An Appeal for Inquiry.” Mennonite Quarterly Review 44(3):376-88.

Liepins, Ruth. 2000. "New Energies for an Old Idea: Reworking Approaches to 'Community' in Contemporary Rural Studies.” Journal of Rural Studies 16(1):23-35.

Luthy, David. 1986. The Amish in America: Settlements that Failed, 1840-1960. Aylmer, ON: Pathway Publishers.

Luthy, David. 1994. “Amish Migration Patterns: 1972-1992.” Pp. 243-59 in The Amish Struggle with Modernity, edited by Donald Kraybill and Marc Olshan. Hanover, NH: University Press of New England.

Luthy, David. 1997. Why Some Amish Communities Fail: Extinct Settlements, 1961-2003. Aylmer, ON: Pathway.

Luthy, David. 2009. Amish Settlements across America: 2008. Aylmer, ON: Pathway.

Markle, Gerald, and Sharon Pasco. 1977. "Family Limitation among the Old Order Amish.” Population Studies 31(2):267-80.

Martin, Donald. 2003. Old Order Mennonites of Ontario: Gelassenheit, Discipleship, Brotherhood. Kitchener, ON: Pandora Press.

Matthews, Samuel. 2001. The Development of Missional Vision in a Midwestern Amish Mennonite Congregation. Doctoral dissertation in ministry. Pasadena, CA: Fuller Theological Seminary.

McQuire, Meredith. 2002. Religion: The Social Context. Belmont, CA: Wadsworth.

Meyers, Thomas, and Steven Nolt. 2005. An Amish Patchwork: Indiana's Old Orders in the Modern World. Bloomington, IN: Indiana University Press.

Miller, Devon (ed.). 2004. Kentucky \& Tennessee Amish Directory with Pinecraft, FL \& Beeville, TX. Millersburg, OH: Abana Books, Ltd.

Nolt, Steven. 2003. A History of the Amish. Intercourse, PA: Good Books.

Nolt, Steven, and Thomas Meyers. 2007. Plain Diversity: Amish Cultures \& Identities. Baltimore, MD: Johns Hopkins University Press. 
Olshan, Marc. 1981. "Modernity, the Folk Society, and the Old Order Amish: An Alternative Interpretation.” Rural Sociology 46(2):297-309.

Pride, Richard. 2003. “Elmo Stoll and the Christian Community at Cookeville.” Border States: Journal of the Kentucky-Tennessee American Studies Association 14:36-49.

Raith, Joachim. 2003. “The Speech Island 'Big Valley' as a Speech Community.” Pp. 53-67 in German Language Varieties Worldwide: Internal and External Perspectives, edited by W.D. Keel and K.J. Mattheier. Frankfurt, Germany: Peter Lang.

Reschly, Steven. 2000. The Amish on the Iowa Prairie: 1840-1910. Baltimore, MD: Johns Hopkins University Press.

Schwieder, Elmer, and Dorothy Schwieder. 1976. "The Paradox of Change in the Life Style of Iowa's Old Order Amish.” International Review of Modern Sociology 6(Spring):69-74.

Scott, Stephen. 1996. An Introduction to Old Order and Conservative Mennonite Groups. Intercourse, PA: Good Books.

Smith, William. 2013. "Continuity and Change in a Southern Beachy Amish-Mennonite Congregation.” Journal of Amish and Plain Anabaptist Studies 1(2):48-68.

Stevick, Richard. 2007. Growing up Amish: The Teenage Years. Baltimore, MD: Johns Hopkins University Press

Testa, Randy-Michael. 1992. After the Fire: The Destruction of the Lancaster County Amish. Hanover, NH: University Press of New England.

Waldrep, G.C. 2008. “The New Order Amish and Para-Amish Groups: Spiritual Renewal within Tradition.” Mennonite Quarterly Review 82(3):395-426.

Warren, Roland. 1978. Community in America ( ${ }^{\text {rd }}$ ed.). Chicago, IL: Rand McNally.

Wasao, Samson, and Donnermeyer, Joseph F. 1996. “An Analysis of Factors Related to Parity among the Amish in Northeast Ohio.” Population Studies 50(2):235-46.

Woodberry, Robert, and Christian Smith. 1998. "Fundamentalism et al.: Conservative Protestants in America.” Annual Review of Sociology 24:25-56.

Yoder, John Howard (ed.). 1977. The Schleitheim Confession. Scottdale, PA: Herald Press.

Yoder, Nathan. 2014. Together in the Work of the Lord: A History of the Conservative Mennonite Conference. Scottdale, PA: Herald Press.

Yoder, Paton. 1991. Tradition and Transition: Amish Mennonites and Old Order Amish 18001900. Scottdale, PA: Herald Press. 
Zimmerman Umble, Diane. 1994. "The Amish and the Telephone: Resistance and Reconstruction.” Pp. 183-94 in Consuming Technologies: Media and Information, edited by Roger Silverstone and Eric Hirsch: New York, NY: Routledge.

Zook, Lee. 2003. “Slow-Moving Vehicles.” Pp. 143-161 in The Amish and the State, edited by Donald Kraybill. Baltimore, MD: Johns Hopkins University Press.

\section{Appendix}

Table 1: Amish Settlements in Kentucky (as of October 31, 2014)

\begin{tabular}{|c|c|c|c|c|c|c|c|}
\hline Name of Settlement & Group & County & Est. & End & Origin & Districts & Pop. \\
\hline Guthrie & NOA & Todd & 1958 & & Va. & 3 & 417 \\
\hline Franklin A-M & Bc A-M & Simpson & 1966 & & Va. & {$[1]$} & 137 \\
\hline Crofton & NOA & Christian & 1972 & & Mo. & 2 & 231 \\
\hline$\overline{\text { Casey Amish }}$ & MWB & Casey & 1974 & & Md. & {$[1]$} & 128 \\
\hline Marion & OOA & Crittenden & 1977 & & De. & 4 & 556 \\
\hline Plainview Mennonite & Bc A-M & Logan & 1978 & & Ky. (Franklin) & {$[1]$} & 83 \\
\hline Dunnville/Columbia & OOA & Casey \& Adair & 1978 & & Pa. & 1 & 74 \\
\hline Flemingsburg & NOA & Fleming & 1981 & 1984 & [Unknown] & - & - \\
\hline Hickory A-M & MWB & Graves & 1982 & & Tn. & {$[1]$} & 103 \\
\hline Glasgow & OOA & Barren & 1982 & & [Unknown] & 1 & 176 \\
\hline Mt. Carmel Bible F. & MCF & Fleming & 1984 & & Ky. (local NOA) & {$[1]$} & 100 \\
\hline Park City/Smith’s Grove & SwA & Barren \& Warren & 1984 & & Tn. & 3 & 244 \\
\hline Providence Mennonite F. & Bc A-M & Simpson & 1986 & & Ky. (Franklin) & {$[1]$} & 122 \\
\hline Sonora/Upton & OOA & Hardin & 1986 & & [Unknown] & 1 & 131 \\
\hline Gradyville & OOA & Cumberland & 1987 & 2007 & [Unknown] & - & - \\
\hline Munfordville/Horse Cave & OOA & Hart \& Grayson & 1989 & & Oh. & 13 & 1,567 \\
\hline Hopkinsville/Pembroke & OOA & $\begin{array}{l}\text { Christian, Logan, Trigg, } \\
\text { Ky, \& Montgomery, TN }\end{array}$ & 1989 & & Pa. & 6 & $1,158^{*}$ \\
\hline Springfield & OOA & Washington & 1990 & 2001 & Pa. & - & - \\
\hline Hardyville/Three Springs & OOA & Hart \& Metcalfe & 1991 & & [Unknown] & 2 & 286 \\
\hline Sonora & SwA & Hardin \& Larue & 1991 & & Tn. and Ny. & 2 & 304 \\
\hline Cedar Springs A-M & A A-M & Grayson & 1993 & & Ky. (Plainview) & {$[1]$} & 125 \\
\hline Pleasant Ridge A-M & A A-M & Wayne & 1993 & & Tn. \& In. & {$[1]$} & 114 \\
\hline Salem & OOA & Livingston \& Crittenden & 1993 & & [Unknown] & 1 & 97 \\
\hline Crab Orchard & OOA & Lincoln \& Rockcastle & 1994 & & Ky. (Gradyville) & 4 & 445 \\
\hline Hustonville & OOA & Lincoln & 1995 & 1998 & [Unknown] & - & - \\
\hline Mercer Bible Fellowship & MCF & Mercer & 1996 & & Ky. (Mt. Carmel) & {$[1]$} & 130 \\
\hline
\end{tabular}




\begin{tabular}{|c|c|c|c|c|c|c|c|}
\hline Name of Settlement & Group & County & Est. & End & Origin & Districts & Pop. \\
\hline Merrimac & OOA & Taylor & 1996 & 2004 & Mi. & - & - \\
\hline$\overline{\text { Deer Creek A-M }}$ & MWB & Webster & 1997 & & Ky. (Hickory) & {$[1]$} & 106 \\
\hline Hudson/Harned & OOA & Breckinridge & 1997 & & In. & 2 & 176 \\
\hline Lewisburg & OOA & Logan & 1998 & & Ky. (Gradyville) & 2 & 252 \\
\hline $\begin{array}{l}\text { Summersville Mennonite } \\
\text {. }\end{array}$ & A A-M & Green & 1999 & & Ky. (Cedar Springs) & [1] & 140 \\
\hline Burkesville & NOA & Cumberland & 1999 & 2003 & Mi. \& Nc. & - & - \\
\hline Hillsboro & OOA & Fleming & 1999 & & Ky. (Dunnville) & 2 & 256 \\
\hline Princeton & NOA & Caldwell \& Lyon & 2001 & & Ky. (Guthrie) & 1 & 66 \\
\hline Fancy Farm/Mayfield & OOA & Hickman \& Graves & 2001 & & Mo. & 1 & 95 \\
\hline Mayfield & SwA & Graves & 2002 & & Tn. & 1 & 152 \\
\hline Pleasant Hill Mennonite & $\mathrm{Br} A-\mathrm{M}$ & Harrison & 2002 & & Ky. (Pl. Ridge A-M) & [1] & 103 \\
\hline$\overline{\text { Cadiz }}$ & OOA & Trigg & 2002 & & Pa. & 1 & 121 \\
\hline Turner Station & OOA & Henry \& Carroll & 2002 & & [Unknown] & 1 & 121 \\
\hline Marrowbone Chr. Br. & U A-M & Cumberland & 2003 & & Ky. (local NOA) & {$[1]$} & 112 \\
\hline $\begin{array}{l}\text { Campbellsville/ } \\
\text { Mannsville }\end{array}$ & OOA & Taylor & 2004 & & Mi. & 1 & 142 \\
\hline $\begin{array}{l}\text { Flemingsburg/ } \\
\text { Poplar Grove }\end{array}$ & OOA & Fleming & 2004 & & Pa. & 2 & 34 \\
\hline Mays Lick & OOA & Mason & 2004 & & In. & 2 & 203 \\
\hline Irvington & OOA & Breckinridge & 2004 & & Pa. & 1 & 121 \\
\hline Living Rock Mennonite & U A-M & Logan & 2005 & 2007 & Ky. (Frkln \& Prv) & {$[1]$} & - \\
\hline Tollesboro & AW/D & Lewis & 2005 & & Oh. & 1 & 103 \\
\hline $\begin{array}{l}\text { Carlisle } \\
\text { nas }\end{array}$ & OOA & Nicholas & 2006 & & In. & 1 & 85 \\
\hline Centertown & OOA & Ohio & 2007 & 2011 & Il. & - & - \\
\hline Fredonia Mennonite & A A-M & Caldwell & 2009 & & Tn. & {$[1]$} & 71 \\
\hline Owenton A-M & A A-M & Owen & 2010 & & Ky. (Cedar Springs) & [1] & 56 \\
\hline Caneyville / Morgantown & OOA & Grayson & 2010 & & Il. \& On. & 1 & 70 \\
\hline Willisburg/Springfield & OOA & Washington & 2010 & & Oh. & 1 & 65 \\
\hline Owingsville & OOA & Bath & 2010 & & In. \& Mi. & 1 & 98 \\
\hline Leitchfield & SwA & Grayson & 2011 & & $\begin{array}{l}\text { Ky. (Park City/ } \\
\text { Smith’s Grove) }\end{array}$ & 1 & 70 \\
\hline Hawesville & OOA & Hancock & 2011 & & Ky. (Crab Orchard) & 1 & 103 \\
\hline Gravel Switch/Perryville & OOA & Boyle \& Marion & 2011 & & Mi. (Newago) & 1 & 103 \\
\hline Liberty & SwA & Casey & 2013 & & Mn. (Staples) & 1 & $38(6)^{\dagger}$ \\
\hline Pleasureville & OOA & Henry & 2013 & & In. (Vevay) & 1 & $65(8) \dagger$ \\
\hline Summer Shade & OOA & Metcalfe & 2013 & & Mo. (Bethany) & 1 & $35(6) \dagger$ \\
\hline Annville/London & OOA & Jackson \& Laurel & 2014 & & [Unknown] & 1 & 17 \\
\hline Olive Hill & OOA & Carter & 2014 & & $\begin{array}{l}\text { Pa. (Troutville / } \\
\text { Puxsutawney) }\end{array}$ & 1 & 17 \\
\hline
\end{tabular}

*Eleven Amish from the Hopkinsville / Pembroke community live in Montgomery County, Tennessee $\dagger$ Indicates population estimate confidence level (see Donnermeyer, Anderson, and Cooksey 2013). 
Table 2: Amish Population in Kentucky, by County

\begin{tabular}{|c|c|c|c|c|}
\hline County & Settlement Name & Group & Pop. & \% of County Pop. \\
\hline Adair & Dunnville/Columbia (partial) & OOA & 59 & $0.032 \%$ \\
\hline \multirow[t]{3}{*}{ Barren } & Glasgow & OOA & 176 & \\
\hline & Park City/Smith’s Grove (partial) & SwA & 161 & \\
\hline & & & 337 & $0.8 \%$ \\
\hline Bath & Owingsville & OOA & 98 & $0.845 \%$ \\
\hline Boyle & Gravel Switch / Perryville (partial) & OOA & 52 & $0.179 \%$ \\
\hline \multirow[t]{3}{*}{ Breckinridge } & Hudson/Harned & OOA & 176 & \\
\hline & Irvington & OOA & 121 & \\
\hline & & & 297 & $1.481 \%$ \\
\hline \multirow[t]{3}{*}{ Caldwell } & Princeton (partial) & NOA & 19 & \\
\hline & Fredonia Mennonite & A A-M & 71 & \\
\hline & & & 90 & $0.693 \%$ \\
\hline Carroll & Turner Station & OOA & 40 & $0.37 \%$ \\
\hline Carter & Olive Hill & OOA & 17 & $0.062 \%$ \\
\hline \multirow[t]{4}{*}{ Casey } & Casey Amish & MWB & 128 & \\
\hline & Dunnville/Columbia (partial) & OOA & 15 & \\
\hline & Liberty & SwA & 38 & \\
\hline & & & 181 & $1.127 \%$ \\
\hline \multirow[t]{3}{*}{ Christian } & Crofton & NOA & 231 & \\
\hline & Hopkinsville/Pembroke (partial) & OOA & 895 & \\
\hline & & & 1,126 & $1.532 \%$ \\
\hline \multirow[t]{3}{*}{ Crittenden } & Marion & OOA & 556 & \\
\hline & Salem (partial) & OOA & 56 & \\
\hline & & & 612 & $6.57 \%$ \\
\hline Cumberland & Marrowbone Christian Brotherhood & U A-M & 112 & $1.634 \%$ \\
\hline \multirow[t]{4}{*}{ Fleming } & Mt Carmel Bible Fellowship & M.C.F. & 100 & \\
\hline & Hillsboro & OOA & 256 & \\
\hline & Flemingsburg/Poplar Grove & OOA & 34 & \\
\hline & & & 390 & $2.718 \%$ \\
\hline \multirow[t]{4}{*}{ Graves } & Hickory A-M & MWB & 103 & \\
\hline & Fancy Farm/Mayfield (partial) & OOA & 29 & \\
\hline & Mayfield & SwA & 152 & \\
\hline & & & 284 & $0.765 \%$ \\
\hline \multirow[t]{5}{*}{$\begin{array}{l}\text { Grayson } \\
\end{array}$} & Munfordville/Horse Cave (partial) & OOA & 9 & \\
\hline & Cedar Springs A-M & A A-M & 125 & \\
\hline & Caneyville & OOA & 70 & \\
\hline & Leitchfield & OOA & 70 & \\
\hline & & & 274 & $1.0642 \%$ \\
\hline Green & Summerville Mennonite & A A-M & 140 & $1.214 \%$ \\
\hline Hancock & Hawesville & OOA & 24 & $0.28 \%$ \\
\hline Hardin & Sonora/Upton & OOA & 131 & $0.124 \%$ \\
\hline
\end{tabular}




\begin{tabular}{|c|c|c|c|c|}
\hline County & Settlement Name & Group & Pop. & \% of County Pop. \\
\hline \multirow[t]{3}{*}{ Hart } & Munfordville/Horse Cave (partial) & OOA & 1,558 & \\
\hline & Hardyville/Three Springs (partial) & OOA & 143 & \\
\hline & & & 1,701 & $9.347 \%$ \\
\hline Harrison & Pleasant Hill Mennonite & $\mathrm{Br} \mathrm{A}-\mathrm{M}$ & 103 & $0.547 \%$ \\
\hline \multirow[t]{3}{*}{ Henry } & Turner Station (partial) & OOA & 81 & \\
\hline & Pleasureville & OOA & 65 & \\
\hline & & & 146 & $0.945 \%$ \\
\hline Hickman & Fancy Farm/Mayfield & OOA & 66 & $1.346 \%$ \\
\hline Jackson & Annville/London (partial) & OOA & 9 & $0.067 \%$ \\
\hline Larue & Sonora & SwA & 304 & $2.142 \%$ \\
\hline Laurel & Annville/London (partial) & OOA & 8 & $0.013 \%$ \\
\hline Lewis & Tollesboro & AW/D & 103 & $0.743 \%$ \\
\hline Lincoln & Crab Orchard (partial) & OOA & 426 & $1.722 \%$ \\
\hline Livingston & Salem (partial) & OOA & 41 & $0.431 \%$ \\
\hline \multirow[t]{4}{*}{ Logan } & Plainview Mennonite & Bc A-M & 83 & \\
\hline & Hopkinsville/Pembroke (partial) & OOA & 146 & \\
\hline & Lewisburg & OOA & 252 & \\
\hline & & & 481 & $1.792 \%$ \\
\hline Lyon & Princeton (partial) & NOA & 47 & $0.565 \%$ \\
\hline Marion & Gravel Switch / Perryville (partial) & OOA & 51 & $0.025 \%$ \\
\hline Mason & Mays Lick & OOA & 203 & $1.161 \%$ \\
\hline Mercer & Mercer Bible Fellowship & M.C.F. & 130 & $0.061 \%$ \\
\hline \multirow[t]{3}{*}{ Metcalfe } & Hardyville/Three Springs (partial) & OOA & 143 & \\
\hline & Summer Shade & OOA & 35 & \\
\hline & & & 178 & $1.783 \%$ \\
\hline Nichols & Carlisle & OOA & 85 & $1.191 \%$ \\
\hline Owen & Owenton A-M & A A-M & 56 & $0.517 \%$ \\
\hline Rockcastle & Crab Orchard (partial) & OOA & 19 & $0.111 \%$ \\
\hline \multirow[t]{3}{*}{ Simpson } & Franklin A-M & Bc A-M & 137 & \\
\hline & Provience Mennonite Fellowship & Bc A-M & 122 & \\
\hline & & & 259 & $1.495 \%$ \\
\hline Taylor & Campbellsville/Mannsville & OOA & 142 & 0.579 \\
\hline \multirow[t]{3}{*}{ Trigg } & Hopkinsville/Pembroke (partial) & OOA & 106 & \\
\hline & Cadiz & OOA & 121 & \\
\hline & & & 227 & $1.583 \%$ \\
\hline Todd & Guthrie & OOA & 417 & $3.347 \%$ \\
\hline Warren & Park City/Smith’s Grove (partial) & SwA & 83 & $0.0729 \%$ \\
\hline Washington & Willisburg/Springfield & OOA & 65 & $0.555 \%$ \\
\hline Wayne & Pleasant Ridge A-M & U A-M & 114 & $0.548 \%$ \\
\hline Webster & Deer Creek A-M & MWB & 106 & $0.778 \%$ \\
\hline Total & & & 9,834 & $0.224 \%$ \\
\hline
\end{tabular}




\section{Table 3: Other Plain Anabaptist Congregations in Kentucky}

\begin{tabular}{|c|c|c|c|c|}
\hline Name & County & Group & Est. & Population \\
\hline \multicolumn{5}{|c|}{ OLD ORDER MENNONITE } \\
\hline Cedar Hill & Casey & Groffdale Conference & 1979 & 17 (Households) \\
\hline Meadow Valley & Christian & Groffdale Conference & 1991 & $58(\mathrm{HH})$ \\
\hline Strington & Todd & Groffdale Conference & 2010 & $57(\mathrm{HH})$ \\
\hline Miller Valley & Todd & John Martins (76ers) & $2000 \mathrm{~s}$ & 55 (Members) \\
\hline Flemingsburg & Fleming & Virginia (Cline) & $2010 c$ & - \\
\hline Cerulean & Trigg & Orthodox (Gorries) & - & $59(\mathrm{M})$ \\
\hline Fairview & Todd & Orthodox (Gorries) & - & - \\
\hline Oakwood & Allen & Hoover (Scottsville) & 1978 & - \\
\hline Red Hill & Allen & Hoover (Scottsville) & - & - \\
\hline Holland & Allen & Hoover (Scottsville) & 1994 & - \\
\hline Henry Hoover & Todd & Reidenbach (35ers) & 1990 & $80(\mathrm{M})$ \\
\hline Dan M. Hoover & Grayson & Reidenbach (35ers) & $2009 c$ & $65(\mathrm{M})$ \\
\hline Amos Martin & Todd & Reidenbach (35ers) & & $55(\mathrm{M})$ \\
\hline Elk Horn & Casey & Stauffer (Pikers) & 1987 & $34(\mathrm{M})$ \\
\hline \multicolumn{5}{|c|}{ CONSERVATIVE MENNONITE } \\
\hline Solid Rock & Casey & B.M.A. & 2007 & $13(\mathrm{M})$ \\
\hline Willow Creek & Logan & Unaffiliated (Cat. B) & 2000 & $70(\mathrm{M})$ \\
\hline Breckinridge & Breckinridge & Nationwide F. & 1996 & $90(\mathrm{M})$ \\
\hline Faith Hills & Morgan & Nationwide F. & 1960 & $67(\mathrm{M})$ \\
\hline Grayson & Carter & Nationwide F. & 2005 & $60(\mathrm{M})$ \\
\hline Hope Valley & Johnson & Nationwide F. & 1990 & $74(\mathrm{M})$ \\
\hline Valley View & Knott & Nationwide F. & 1963 & $63(\mathrm{M})$ \\
\hline Lincoln County & Lincoln & Wash.-Fr. Conf. & 1998 & $68(\mathrm{M})$ \\
\hline Paces Creek & Clay & Wash.-Fr. Conf. & 1978 & $65(\mathrm{M})$ \\
\hline Mt. Hermon & Monroe & Tn. Churches & 1978 & $97(\mathrm{M})$ \\
\hline
\end{tabular}

CHURCH OF GOD IN CHRIST, MENNONITE (HOLDEMAN)

\begin{tabular}{|c|c|c|c|c|}
\hline Harmony & Graves & CoGiC,M (Holdeman) & 1989 & $150(\mathrm{M})$ \\
\hline Fountain Run & Monroe & CoGiC,M (Holdeman) & 2002 & $112(\mathrm{M})$ \\
\hline Liberty & Casey & CoGiC,M (Holdeman) & 2009 & $20(\mathrm{M})$ \\
\hline Mount Pleasant & Graves & CoGiC,M (Holdeman) & 2004 & $120(\mathrm{M})$ \\
\hline \multicolumn{5}{|c|}{ INTENTIONAL CHURCHES } \\
\hline Simon Beachy & Monroe & Unaffiliated & 1996 & $32(\mathrm{HH})^{\dagger}$ \\
\hline Caneyville & Grayson & Christian Communities & 2004 & $18(\mathrm{HH})$ \\
\hline Brownsville & Edmonson & Christian Communities & 2010c & $6(\mathrm{HH})$ \\
\hline Blessed Hope & Casey & Remnant (Charity) & 2005 & $66(\mathrm{M})$ \\
\hline \multicolumn{5}{|c|}{ APOSTOLIC CHRISTIAN CHURCH } \\
\hline
\end{tabular}

Lexington Clark $\quad$ Apostolic CC of America 1975 3 (M)

$\dagger$ Based on the decade-old figure from Waldrep (2008). 